INDONESIA ACCOUNTING JOURNAL

VOLUME 1, NUMBER 1, YEAR 2019

${ }^{1}$ Corresponding author

Jurusan Akuntansi

Fakultas Ekonomi dan Bisnis

Universitas Sam Ratulangi

Jl. Kampus UNSRAT

Manado, Indonesia, 95115

E-mail : pogagaangelica@gmail.com

${ }^{2,3}$ Jurusan Akuntansi

Fakultas Ekonomi dan Bisnis

Universitas Sam Ratulangi

Jl. Kampus UNSRAT

Manado, Indonesia, 95115

Article info:

Received 16 October 2019

Accepted 16 October 2019

Available online 16 October 2019

Keywords: SAK ETAP; recording;

valuation method; inventory; and raw material

JEL Classification: M41

DOI : http://doi.org/10.32400/iaj. 25745

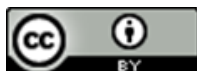

\section{Penerapan metode pencatatan dan penilaian atas persediaan bahan baku pada Dolphin Donuts Bakery Manado_}

\author{
Angelica C. Pogaga ${ }^{1}$ \\ Sifrid S. Pangemanan ${ }^{2}$ \\ Jessy D. L. Warongan ${ }^{3}$
}

\begin{abstract}
Inventories are assets that are held for sale in the normal course of business or goods that are used or consumed in production to be sold. For companies, inventory is a very important asset because with the company's inventory can maintain its survival. The problem that often occurs in inventory accounting is recording and valuation. The purpose of this research is determine the suitability of the application of recording and valuation or raw material inventories at Dolphin Donuts Bakery Manado with the Statement of Financial Accounting Standards for Entities without Public Accountability (SAK ETAP). Dolphin Donuts Bakery Manado is a company engaged in the food industry that produces a variety of breads, pastries, donuts and birthday cakes. The method used in this research is descriptive qualitative method. Based on research results obtained that method of recording inventories is not all in accordance with SAK ETAP. Whereas the valuation of raw material inventories applied by Dolphin Donuts Bakery Manado is in accordance with the Statement of Financial Accounting Standards for Entities without Public Accountability (SAK ETAP) Chapter 11 Regarding Inventories.
\end{abstract}

\section{Pendahuluan}

Persediaan merupakan barang dagang yang disimpan kemudian dijual kembali atau barang dalam proses yang digunakan dalam proses produksi kemudian dijual dalam kegiatan bisnis perusahaan (Novatiani et.al, 2017). Dalam perusahaan persediaan mempengaruhi laba rugi dan neraca. Untuk mendapatkan hasil hasil yang maksimum, maka perlu adanya pengawasan serta membantu tercapainya tingkat efisiensi biaya pada persediaan (Ivantry, 2016). Saputra (2013) dalam sistem perpetual, setiap perubahan yang terjadi atas persediaan langsung dicatatkan pada perkiraan persediaan, sehingga setiap saat perusahaan bisa mengetahui jumlah dan harga perolehan persediaan barang yang ada digudang. Namun, setahun sekali perlu diadakan pengecekan apakah jumlah barang dalam gudang sesuai dengan jumlah dalam rekening persediaan. Sedangkan sistem periodik, seluruh perubahan yang terjadi dalam persediaan tidak secara langsung dicatatkan pada perkiraan persediaan.

\section{Tinjauan pustaka}

Akuntansi. American Institute of Certified Public Accountans dikutip oleh Harahap (2011:5), akuntansi merupakan sebuah seni mencatat, menggolongkan dan meringkas transaksi dan kejadian yang bersifat keuangan dengan cara tertentu dan dalam bentuk satuan uang serta menafsirkan hasilhasilnya. Weygandt et.al., (2011:1) akuntansi adalah sistem informasi yang mengidentifikasi, mencatat dan mengkomunikasikan peristiwa ekonomi dari suatu organisasi kepada pihak yang memiliki kepentingan.

Akuntansi Keuangan. Karongkong et.al., (2018), akuntansi keuangan merupakan salah satu bidang akuntansi yang berhubungan dalam menyediakan informasi 
akuntansi yang berhubungan dengan penyajian laporan keuangan bagi pemakai atau pengambil keputusan yang ada diluar organisasi atau pihak eksternal, seperti kreditur, investor dan lain-lain.

Persediaan. Syakur

persediaan meliputi barang yang menjadi objek pokok aktivitas perusahaan yang tersedia untuk digunakan dalam proses produksi atau dijual, pada perusahaan dagang barang-barang yang diadakan (dibeli) untuk dijual kembali. Weygandt et.al., (2011:408) menyatakan "Inventories are asset items that a company hold's for sale in the ordinary course of business or goods that it will use or consume in the production of goods to be sold".

Jenis-jenis persediaan. Halim (2012 : 22) terdapat tiga jenis persediaan, diantaranya: (a) persediaan bahan baku, adalah bahan mentah yang belum diusahakan untuk diproses di dalam produksi; (b) persediaan barang dalam proses, merupakan bahan yang belum selesai diproduksi; dan (c) persediaan barang jadi.

\section{Sistem pencatatan persediaan}

Sistem pencatatan perpetual (perpetual inventory system). Tjahjono (2009:59) sistem perpetual adalah sistem pencatatan persediaan yang mengikuti mutasi persediaan barang setiaap saat diketahui rekening perusahaan.

Sistem pencatatan periodik (periodik inventory system). Tjahjono (2009:59) sistem periodik ialah sistem pencatatan persediaan yang tidak mengikuti mutasi persediaan, sehingga untuk mengetahui jumlah persediaan pada saat tertentu maka harus mengadakan perhitungan fisik pada persediaan.

\section{Metode penilaian persediaan}

Metode identifikasi khusus. Santoso (2010:56) dalam metode identifikasi khusus penilaian persediaan dilakukan berdasarkan identifikasi barang masing-masing, karena itu dalam praktik penerapan metode ini tidak mudah dilakukan dan apabila ditinjau dari segi pengelolaannya pun biasanya manfaat yang didapat lebih kecil daripada pengorbanan yang harus dilakukan untuk melakukan penilaian itu sendiri.
Metode FIFO. Stice dan Skousen (2011:667) metode first in first out intinya barang yang lebih dulu terjual merupakan barang yang dibeli pertama. Metode first in first out menghasilkan nilai persediaan yang besar dan nilai harga pokok penjualan yang kecil ketika harga naik.

Metode Rata-Rata (Average). Syakur (2015:162) metode rata-rata (average) intinya dalam menentukan harga perolehan tidak berdasarkan pada harga persediaan awal atau terakhir masuk. Maka dari itu keuntungan dan kelemahan dari metode FIFO dan LIFO tereliminasi pada posisi rata-rata.

Metode LIFO. Stice dan Skousen (2011:667) metode LIFO adalah barang yang lebih dulu terjual merupakan barang yang masuk terakhir. Metode LIFO menghasilkan nilai persediaan yang kecil dan harga pokok penjualan yang besar ketika harga naik.

Penelitian terdahulu. Barchelino (2016) menunjukkan bahwa metode pencatatan yang digunakan perusahaan adalah metode perpetual terkomputerisasi dan untuk menilai persediaan barang dagangan perusahaan menggunakan metode First In First Out (FIFO), sehingga telah sesuai dengan PSAK No. 14 (Revisi 2015). Wullur et.al., (2016) menunjukkan bahwa PT. Gatraco Indah Manado mencatat persediaan barang menggunakan sistem pencatatan perpetual, sedangkan dalam menilai persediaan perusahaan menggunakan metode FIFO, sehingga telah sesuai dengan PSAK No. 14 (Revisi 2014). Rondonuwu et.al., (2016) menunjukkan bahwa penerapan metode persediaan First In First Out (FIFO) dan sistem pencatatan perpetual oleh perusahaan sudah baik dan sesuai sehingga dengan menggunakan metode FIFO, persediaan akhir telah tercatat pada harga yang terbaru sehingga persediaan akhir dinilai dengan harga pokok pembelian yang paling akhir.

\section{Metode penelitian}

Metode penelitian yang digunakan dalam penelitian ini adalah metode deskriptif, yaitu dengan menguraikan suatu keadaan nyata yang di temukan, kemudian menganalisis 
data yang ada hubungannya dengan pencatatan dan penilaian persediaan. Proses analisis data yang berkaitan dengan metode pencatatan dan penilaian persediaan bahan baku adalah sebagai berikut :

1. Tahap pertama. Dimulai dengan mengumpulkan data dari pihak pengawasan, manager dan staf bagian produksi di Dolphin Donuts Bakery Manado, data tersebut berupa hasil wawancara, kartu persediaan, penjualan dan pembelian.

2. Tahap kedua. peneliti mulai menganalisis data dengan cara menghitung persediaan bahan baku (persediaan awal : kuantitas).

3. Tahap ketiga, peneliti menarik kesimpulan dari hasil analisis data.

\section{Hasil penelitian dan pembahasan \\ Hasil penelitian}

Jenis-jenis persediaan. Berdasarkan hasil wawancara dapat dilihat bahwa Dolphin Donuts Bakery Manado merupakan perusahaan yang bergerak dibidang industri makanan yang memproduksi kue kering, kue ultah, donut, dan roti. Jenis persediaan yang dimiliki Dolphin Donuts Bakery Manado merupakan persediaan bahan baku.

\section{Metode pencatatan persediaan}

Pembelian persediaan. Pembelian Persediaan dilakukan dengan menggunakan dua cara yakni pembelian secara tunai dan kredit. Untuk pembelian secara tunai perusahaan bisa langsung mentransfer uang tersebut kepada perusahaan pemasok, sedangkan untuk pembelian secara kredit perusahaan pemasok memberikan syarat kepada Dolphin Donuts Bakery Manado berupa NPWP (Nomor Pokok Wajib Pajak). Untuk lamanya term of payments perusahaan pemasok memberikan waktu 30 hari sejak tanggal pembelian barang, dengan kata lain perusahan harus melunasi pembelian barang dagangan dalam jangka waktu 30 hari kepada perusahaan pemasok. Tabel 1 merupakan kartu persediaan (pembelian) bahan baku yang digunakan selama proses produksi bulan April 2018 yang berjumlah Rp. 108.723.000. Pembelian persediaan bahan baku pada bulan April lebih besar dikarenakan terdapat beberapa pesanan khusus. Berdasarkan hasil wawancara yang diperoleh dari Kepala Cheff, dapat dilihat bahwa Dolphin Donuts Bakery Manado dalam pencatatan persediaan bahan baku menggunakan metode pencatatan perpetual. Setiap terjadinya transaksi pembelian persediaan, Dolphin Donuts Bakery Manado mencatatnya dalam kartu persediaan. Dolphin Donuts Bakery Manado mencatat pembelian berdasarkan pada harga pembelian saja tanpa memasukkan unsur lainnya seperti biaya angkut.

Tabel 1. Kartu Persediaan (pembelian) bulan April 2018

\begin{tabular}{|c|c|c|c|}
\hline Tanggal & Keterangan & $\begin{array}{l}\text { Harga Satuan } \\
\text { (Rp) }\end{array}$ & $\begin{array}{c}\text { Jumlah } \\
\text { (Rp) }\end{array}$ \\
\hline \multicolumn{4}{|c|}{ PT. BERDIKARI } \\
\hline \multirow[t]{2}{*}{1} & $\begin{array}{l}\text { Tepung terigu, } \\
50 \mathrm{sak}\end{array}$ & $175.000 / \mathrm{sak}$ & 8.750 .000 \\
\hline & Gula pasir, $8 \mathrm{sak}$ & $575.000 / \mathrm{sak}$ & 4.600 .000 \\
\hline \multirow[t]{2}{*}{18} & $\begin{array}{l}\text { Tepung terigu, } \\
50 \mathrm{sak}\end{array}$ & $175.000 / \mathrm{sak}$ & 8.750 .000 \\
\hline & Gula pasir, $5 \mathrm{sak}$ & $575.000 / \mathrm{sak}$ & 2.875 .000 \\
\hline \multicolumn{4}{|c|}{ PT. SUKANDA JAYA } \\
\hline \multirow[t]{2}{*}{1} & $\begin{array}{l}\text { Susu Ultra Milk, } \\
2 \text { karton } \\
\text { SKM }\end{array}$ & $165.500 / \mathrm{ktn}$ & 331.000 \\
\hline & $\begin{array}{l}\text { "Carnation", } 3 \\
\text { karton }\end{array}$ & $550.000 / \mathrm{ktn}$ & 1.650 .000 \\
\hline 10 & $\begin{array}{l}\text { Susu Ultra Milk, } \\
2 \text { karton }\end{array}$ & $165.500 / \mathrm{ktn}$ & 331.000 \\
\hline 16 & $\begin{array}{l}\text { Susu Ultra Milk, } \\
2 \text { karton }\end{array}$ & $165.500 / \mathrm{ktn}$ & 331.000 \\
\hline 18 & $\begin{array}{l}\text { SKM } \\
\text { "Carnation", } 2 \\
\text { karton }\end{array}$ & $550.000 / \mathrm{ktn}$ & 1.100 .000 \\
\hline \multicolumn{4}{|c|}{ UD. TIGA JAYA } \\
\hline \multirow[t]{3}{*}{2} & $\begin{array}{l}\text { Susu bubuk, } 4 \\
\text { sak }\end{array}$ & $1.000 .000 / \mathrm{sak}$ & 4.000 .000 \\
\hline & Ragi, 4 karton & $750.000 / \mathrm{ktn}$ & 3.000 .000 \\
\hline & $\begin{array}{l}\text { Pengembang, } 4 \\
\text { karton }\end{array}$ & $750.000 / \mathrm{ktn}$ & 3.000 .000 \\
\hline 18 & $\begin{array}{l}\text { Susu bubuk, } 3 \\
\text { sak }\end{array}$ & $1.000 .000 / \mathrm{sak}$ & 3.000 .000 \\
\hline 25 & $\begin{array}{l}\text { Susu bubuk, } 1 \\
\text { sak }\end{array}$ & $1.000 .000 / \mathrm{sak}$ & 1.000 .000 \\
\hline \multicolumn{4}{|c|}{ PT. SINAR MEDOW } \\
\hline \multicolumn{4}{|c|}{ INDONESIA } \\
\hline \multirow[t]{3}{*}{1} & $\begin{array}{l}\text { Mentega putih, } \\
15 \text { karton }\end{array}$ & $375.000 / \mathrm{ktn}$ & 3.750 .000 \\
\hline & Butter, 4 karton & $450.000 / \mathrm{ktn}$ & 1.800 .000 \\
\hline & $\begin{array}{l}\text { Margarin, } 15 \\
\text { karton }\end{array}$ & $450.000 / \mathrm{ktn}$ & 6.750 .000 \\
\hline \multirow[t]{2}{*}{16} & $\begin{array}{l}\text { Mentega putih, } 5 \\
\text { karton }\end{array}$ & $375.000 / \mathrm{ktn}$ & 1.875 .000 \\
\hline & Butter, 2 karton & $450.000 / \mathrm{ktn}$ & 900.000 \\
\hline 20 & $\begin{array}{l}\text { Margarin, } \\
\text { karton }\end{array}$ & $450.000 / \mathrm{ktn}$ & 2.250 .000 \\
\hline & ГOTAL & - & 108.723 .000 \\
\hline
\end{tabular}

Sumber: Dolphin Donuts Bakery Manado 
Tabel 1. Kartu Persediaan (pembelian) bulan April 2018

\begin{tabular}{|c|c|c|c|}
\hline Tanggal & Keterangan & $\begin{array}{l}\text { Harga Satuan } \\
\text { (Rp) }\end{array}$ & $\begin{array}{l}\text { Jumlah } \\
\text { (Rp) }\end{array}$ \\
\hline \multicolumn{4}{|c|}{ PT. INDO HARAPAN } \\
\hline \multicolumn{4}{|c|}{ MAKMUR } \\
\hline \multirow[t]{3}{*}{2} & $\begin{array}{l}\text { Coklat batang, } 10 \\
\text { karton }\end{array}$ & $800.000 / \mathrm{ktn}$ & 8.000 .000 \\
\hline & $\begin{array}{l}\text { Coklat bubuk, } 5 \\
\text { sak }\end{array}$ & $650.000 / \mathrm{sak}$ & 3.250 .000 \\
\hline & $\begin{array}{l}\text { Coklat Meses, } 5 \\
\text { karton }\end{array}$ & $475.000 / \mathrm{ktn}$ & 2.375 .000 \\
\hline \multirow[t]{3}{*}{18} & $\begin{array}{l}\text { Coklat batang, } 5 \\
\text { karton }\end{array}$ & $800.000 / \mathrm{ktn}$ & 4.000 .000 \\
\hline & $\begin{array}{l}\text { Coklat bubuk, } 3 \\
\text { sak }\end{array}$ & $650.000 / \mathrm{sak}$ & 1.950 .000 \\
\hline & $\begin{array}{l}\text { Coklat meses, } 2 \\
\text { karton }\end{array}$ & $475.000 / \mathrm{ktn}$ & 950.000 \\
\hline \multicolumn{4}{|c|}{ TOKO ANEKA SARI } \\
\hline \multirow[t]{3}{*}{1} & Garam, 5 ball & $75.000 /$ ball & 375.000 \\
\hline & $\begin{array}{l}\text { Keju "Prochize", } \\
5 \text { karton }\end{array}$ & $880.000 / \mathrm{ktn}$ & 4.400 .000 \\
\hline & Sosis, 3 karton & $110.000 / \mathrm{ktn}$ & 330.000 \\
\hline \multirow[t]{2}{*}{10} & Garam, 5 ball & $75.000 /$ ball & 375.000 \\
\hline & Sosis, 3 karton & $110.000 / \mathrm{ktn}$ & 330.000 \\
\hline \multirow[t]{2}{*}{19} & Garam 5 ball & $75.000 /$ ball & 375.000 \\
\hline & $\begin{array}{l}\text { Keju "Prochize", } \\
3 \text { karton }\end{array}$ & $880.000 / \mathrm{ktn}$ & 2.640 .000 \\
\hline 21 & Sosis, 2 karton & $110.000 / \mathrm{ktn}$ & 220.000 \\
\hline \multicolumn{4}{|c|}{ SUPPLIER LOKAL } \\
\hline 1 & Telur, 2000 biji & $1.300 / \mathrm{biji}$ & 2.600 .000 \\
\hline 4 & Telur, $1000 /$ biji & $1.300 / \mathrm{biji}$ & 1.300 .000 \\
\hline 7 & Telur, 2000 biji & $1.300 / \mathrm{biji}$ & 2.600 .000 \\
\hline 10 & Telur, 1500 biji & 1.300/biji & 1.950 .000 \\
\hline 13 & Telur, 1700 biji & $1.300 / \mathrm{biji}$ & 2.210 .000 \\
\hline 15 & Telur, 1000 biji & $1.300 / \mathrm{biji}$ & 1.300 .000 \\
\hline 18 & Telur, 1200 biji & $1.300 / \mathrm{biji}$ & 1.560 .000 \\
\hline 20 & Telur, 2300 biji & $1.300 / \mathrm{biji}$ & 2.990 .000 \\
\hline 22 & Telur, 1000 biji & $1.300 / \mathrm{biji}$ & 1.300 .000 \\
\hline \multirow[t]{2}{*}{25} & Telur, 1000 biji & $1.300 / \mathrm{biji}$ & 1.300 .000 \\
\hline & OTAL & - & 108.723 .000 \\
\hline
\end{tabular}

Penjualan. Dolphin Donuts Bakery Manado memiliki berbagai macam produk, diantaranya cake pesta, kue kering, Donat dan berbagai jenis roti. Beberapa produk Dolphin Donuts Bakery Manado di pasarkan di beberapa outlet supermarket, serta juga menerima pesanan dari berbagai acara. Untuk pembayaran Dolphin Donuts Bakery Manado hanya menyediakan pembayaran secara tunai, dimana sales mengorder produk yang akan dibeli kemudian diberikan faktur dan cap tunai kemudian disetor kepada kasir.

Metode penilaian persediaan. Dolphin Donuts Bakery Manado dalam menilai persediaan menggunakan metode FIFO, dimana setiap seminggu sekali bahkan dua minggu sekali terjadinya transaksi pembelian persediaan bahan baku. Persediaan bahan baku yang dibeli pertama itulah yang akan dikeluarkan terlebih dahulu dalam proses produksi, kemudian perusahaan akan mengecek sisa stock persediaan apabila stock persediaan tinggal sedikit barulah perusahaan akan membeli kembali persediaan bahan baku. Berdasarkan hasil wawancara, Dolphin Donuts bakery Manado menilai persediaan dengan menggunakan metode First In First Out (FIFO) dimana bahan baku yang dibeli pertama, itu yang pertama diproduksi. Sehingga resiko persediaan tersebut expired sangat kecil, hal ini dikarenakan periode order perusahaan sangat pendek. Hal ini dapat dilihat dalam pencatatan persediaan, dimana transaksi pembelian persediaan bahan baku tepung, gula dan bahan lainnya periode ordernya setiap 2 (dua) minggu sekali dalam sebulan, sedangkan untuk persediaan bahan baku telur periode ordernya setiap 2-3 hari. Hal tersebut dapat diartikan bahwa persediaan yang pertama dibeli itu yang digunakan dalam proses produksi.

\section{Hasil pembahasan}

Jenis-jenis persediaan. Berdasarkan hasil penelitian yang dilakukan, jenis persediaan yang dimiliki oleh Dolphin Donuts Bakery Manado adalah persediaan bahan baku. Perlakuan persediaan pada Dolphin Donuts Bakery Manado ialah dibeli, diolah atau diproduksi untuk dijual kembali. Jenis Persediaan yang dimiliki oleh Dolphin Donuts Bakery Manado telah sesuai dengan SAK ETAP Bab 11 tentang persediaan.. Hal ini juga sejalan dengan yang dikatakan Lantang (2013) dalam penelitiannya yang berjudul "Penerapan Metode Penilaian Persediaan Bahan Baku pada PT. Cargil Indonesia - Copra Crushing Plant Amurang" yang menyatakan bahwa persediaan bahan baku merupakan bahan dasar yang menjadi komponen utama dalam proses produksi.

Metode pencatatan persediaan. Berdasarkan hasil penelitian yang dilakukan, dalam segi pencatatan Dolphin Donuts Bakery Manado menggunakan metode pencatatan perpetual yang hanya mencatat pembelian persediaan bahan baku saja. Dimana setiap terjadinya pembelian persediaan pada perusahan pemasok (principle), Dolphin Donuts Bakery Manado 
mencatatnya dalam kartu persediaan. Dalam kartu persediaan perusahaan hanya mencatat setiap terjadinya pembelian, sedangkan untuk persediaan yang telah keluar atau digunakan dalam proses produksi tidak dicatat dalam kartu persediaan. Hal ini sejalan dengan penelitian Barchelino (2016) dalam penelitiannya yang berjudul "Analisis Penerapan PSAK No. 14 Terhadap Metode Pencatatan dan Penilaian Persediaan Barang Dagangan pada PT. Surya Wenang Indah Manado" dari hasil penelitiannya yang menggunakan metode pencatatan perpetual terkomputerisasi yang telah sesuai dengan Pernyataan Standar Akuntansi Keuangan (PSAK) No. 14 tentang Persediaan.

\section{Metode penilaian persediaan.}

Berdasarkan hasil penelitian yang dilakukan pada Dolphin Donuts Bakery Manado, perusahaan menilai persediaan dengan menggunakan metode First In First Out (FIFO) atau Masuk Pertama Keluar Pertama (MPKP) karena sifat persediaan yang dimiliki Dolphin Donuts Bakery Manado hanya bersifat sementara. Oleh karena itu, perusahaan Dolphin Donuts Bakery Manado dalam menilai persediaan, telah sesuai dengan Standar Akuntansi Keuangan Entitas Tanpa Akuntabilitas Publik (SAK ETAP) Bab 11 tentang Persediaan. Hal ini sejalan dengan penelitian Anwar dan Karamoy (2014) yang berjudul "Analisis Metode Pencatatan dan Penilaian Terhadap Persediaan Barang Dagang Menurut PSAK No. 14 pada PT. Tirta Investama DC Manado", dimana perusahaan dalam menilai persediaannya menggunakan metode Masuk Pertama Keluar Pertama (MPKP) intinya barang yang masuk pertama itu yang diproduksi atau dijual pertama.

\section{Kesimpulan}

Berdasarkan hasil dan pembahasan sebelumnya maka kesimpulan atas penelitian ini adalah: (1) metode pencatatan yang diterapkan pada perusahaan Dolphin Donuts Bakery Manado menggunakan sistem perpetual yang hanya mencatat pembelian saja, setiap terjadinya transaksi pembelian dicatat dalam kartu persediaan. Persediaan yang masuk dicatat dalam kartu persediaan, sedangkan untuk persediaan yang telah keluar atau digunakan dalam proses produksi tidak dicatat oleh perusahaan. Dolphin Donuts Bakery Manado mencatat pembelian berdasarkan harga pembelian saja tanpa memasukkan unsur lain seperti biaya angkut. Dengan demikian pencatatan persediaan pada Dolphin Donuts Bakery Manado sebagian belum sesuai dengan ketentuan yang berlaku pada Standar Akuntansi Keuangan Entitas Tanpa Akuntabilitas Publik (SAK ETAP) Bab 11 Tentang Persediaan; dan (2) untuk metode penilaian persediaan pada Dolphin Donuts Bakery Manado menggunakan metode FIFO dimana metode ini dikembangkan dengan asumsi bahwa barang yang dibeli atau diproduksi pertama kali dianggap dianggap dijual atau dipakai pertama kali, sehingga telah sesuai dengan ketentuan yang berlaku pada Standar Akuntansi Keuangan Entitas Tanpa Akuntabilitas Publik (SAK ETAP) Bab 11 tentang Persediaan. Berdasarkan kesimpulan ini, maka saran dari penelitian ini adalah: (1) dalam sistem pencatatan persediaan yang digunakan perusahaan sudah baik, namun lebih bagus lagi jika mengikuti ketentuan yang berlaku pada SAK ETAP Bab 11 tentang Persediaan; (2) metode penilaian persediaan yang diterapkan oleh perusahaan Dolphin Donuts Bakery Manado telah diterapkan dengan baik sehingga harus dipertahankan oleh perusahaan; dan (3) sebaiknya perusahaan menambah tenaga khusus untuk bagian gudang dan bagian akuntan agar bisa mengawasi kegiatan yang ada digudang, guna untuk meminimalisir terjadinya penyelewengan.

\section{Daftar pustaka}

Anwar, F. N., \& Karamoy, H. (2014). Analisis penerapan metode pencatatan dan penilaian terhadap persediaan barang dagang menurut PSAK No. 14 pada PT. Tirta Investama DC Manado. Jurnal EMBA: Jurnal Riset Ekonomi, Manajemen, Bisnis dan Akuntansi, 2(2), 12961305.

http://ejournal.unsrat.ac.id/index.php/emba/article/ view $/ 4715$

Barchelino, R. (2016). Analisis penerapan PSAK No.14 terhadap metode pencatatan dan penilaian persediaan barang dagang pada PT. Surya Wenang Indah 
Manado. Jurnal EMBA: Jurnal Riset Ekonomi, Manajemen, Bisnis dan Akuntansi, 4(1), 837-846. http://ejournal.unsrat.ac.id/index.php/emba/article/ view/11812

Halim, A. (2012). Dasar-Dasar Akuntansi Biaya. Cetakan Ke Tujuh. Yogyakarta : BPFE.

Harahap, S. S. (2011). Teori Akuntansi. Edisi Revisi 2011. Jakarta : PT Raja Grafindo.

Ikatan Akuntan Indonesia. (2009). Standar Akuntansi Keuangan Entitas Tanpa Akuntabilitas Publik. Jakarta : Dewan Standar Akuntansi Keuangan.

Karongkong, K. R., Ilat, V., \& Tirayoh, V. Z. (2018). Penerapan akuntansi persediaan barang dagang pada UD. Muda-Mudi Tolitoli. Going Concern : Jurnal $\begin{array}{lll}\text { Riset Akuntansi, 13(02), 46-56. } & \text { 13 }\end{array}$ https://doi.org/10.32400/gc.13.02.19082.2018

Lantang, T. M. (2013). Penerapan metode penilaian persediaan bahan baku pada PT. Cargill Indonesia Copra Crushing Plant Amurang. Jurnal EMBA: Jurnal Riset Ekonomi, Manajemen, Bisnis dan Akuntansi, 1(3), 46-54.

http://ejournal.unsrat.ac.id/index.php/emba/article/ view/1371

Novatiani, R. A., Adjeng, R. M. F., \& Lestari, S. (2017). Penerapan sistem pencatatan dan metode penilaian persediaan (pada UKM Deden Batik dan Nanda Batik Tasikmalaya). Jurnal Dharma Bhakti Ekuitas, 02(01), 145-149. Universitas Widyatama Bandung. http://repository.ekuitas.ac.id/123456789/345

Rondonuwu, G., Pangemanan, S. S., \& Mawikere, L. M. (2016). Evaluasi penerapan metode persediaan berdasarkan metode FIFO pada PT. Honda Tunas Dwipa Matra Manado. Jurnal EMBA: Jurnal Riset Ekonomi, Manajemen, Bisnis dan Akuntansi, 04(04), 268278.http://ejournal.unsrat.ac.id/index.php/emba/arti cle/view/13720

Ivantry, R. N. (2016). Analisis metode penilaian persediaan dan pengaruhnya terhadap laporan laba rugi pada PT. Sumber Pangan Nusantara tahun 2013-2015. Skripsi. Fakultas Ekonomi Universitas Nusantara Persatuan Guru Republik Indonesia (UN PGRI) Kediri. http://simki.unpkediri.ac.id/mahasiswa/file_artikel/2 016/12.1.02.01.0275.pdf

Santoso, I. (2010). Akuntansi Keuangan Menengah I. Bandung : Penerbit PT. Rafika Aditama.

Saputra, O. (2013). Analisis akuntansi persediaan barang dagang pada PT. Inti Kreasi Kantor Wilayah Pekan Baru Riau. Skripsi. Jurusan Akuntansi. Fakultas Ekonomi dan Ilmu Sosial Unversitas Islam Negeri Sultan Syarif Kasim Riau. Pekan Baru. http://repository.uin-suska.ac.id/5217/

Stice, J. D., \& Skousen, K. F. (2011). Intermediate Accounting. Jakarta: Salemba Empat.

Syakur, A. (2015). Intermediate Accounting. Jakarta: Penerbit AV Publisher.

Tjahjono, A. (2009). Akuntansi Pengantar 2. Yogyakarta : Ganbika.

Weygandt, J. J., Kieso, D. E., \& Warfield, T. D. (2011). Intermediate Accounting. United States of America:Wiley.

Wullur, R. A. M. L., Karamoy, H., \& Pontoh, W. (2016). Analisis penerapan akuntansi persediaan berdasarkan PSAK No.14 pada PT. Gatraco Indah Manado. Going Concern : Jurnal Riset Akuntansi, 11(1), 1-9. https://doi.org/10.32400/gc.11.1.10552.2016 